\title{
Lake Neor reveals how mountain vegetation responded to 7000 years of hydroclimate variability in northwestern Iran
}

\author{
KHADIJEH ALINEZHAD, ${ }^{1,2}$ ELIAS RAMEZANI, ${ }^{1}$ (1) MORTEZA DJAMALI, ${ }^{3}$ ARASH SHARIFI, ${ }^{4,5}$ (D) ALIREZA NAQINEZHAD, ${ }^{6}$ \\ CYRIL AUBERT, ${ }^{3}$ EMMANUEL GANDOUIN ${ }^{3}$ and ALI POURMAND ${ }^{4}$ \\ ${ }^{1}$ Department of Forestry, Faculty of Natural Resources, Urmia University, Urmia, Iran \\ ${ }^{2}$ Faculty of Mathematics and Natural Sciences, Institute of Prehistoric and Protohistoric Archaeology, \\ Christian-Albrechts-Universität zu Kiel, Kiel, Germany \\ ${ }^{3}$ Institut Méditerranéen de Biodiversité et d'Ecologie marine et continentale, Aix Marseille Univ, CNRS, IRD, Avignon Université, \\ Europôle Méditerranéen de I'Arbois, Aix-en-Provence, France \\ ${ }^{4}$ Neptune Isotope Laboratory (NIL), Department of Marine Geosciences, Rosenstiel School of Marine and Atmospheric Science, \\ University of Miami, Miami, FL, USA \\ ${ }^{5}$ Research and Development Department, BETA analytic-Isobar Science, Miami, FL, USA \\ ${ }^{6}$ Department of Plant Biology, Faculty of Basic Sciences, University of Mazandaran, Babolsar, Iran
}

Received 10 July 2020; Revised 9 March 2021; Accepted 10 March 2021

\begin{abstract}
Palynological and geochemical analyses provide valuable information about modern and past climatic regimes and vegetation. The impact of climate and humans on past vegetation in the semi-arid areas of northwestern Iran has received increased interest in the wake of warming temperatures in the Middle East. Palynological and down-core XRF elemental abundances from a peat core from Lake Neor enabled a reconstruction of vegetational changes of the past 7000 years over the highlands of northwestern Iran. Periods of increased arboreal pollen (AP) types and high (Artemisia + Poaceae)/Chenopodiaceae ratios along with low titanium abundances, high percentages of total organic carbon, more negative $\delta \mathrm{D}$ values, and higher carbon accumulation rates suggest a relatively wet climate. These conditions have persisted during the periods 6700-6200, 5200-4450 and 3200-2200 cal a BP. The overall low AP values, substantial rise of Chenopodiaceae, high $\mathrm{Ti}$ abundances and low values of palaeo-redox proxies, are all evidences of a drier climate, as has been reconstructed for the periods 6200-5200 and 4030-3150 cal a BP and the last 2200 years. An important feature of the last centuries is the increase of anthropogenic and pastoral indicator pollen types. Our results may provide basic data to predict future trends in vegetation dynamics under future climate change in western Asia. Copyright (C) 2021 John Wiley \& Sons, Ltd.
\end{abstract}

KEYWORDS: climate change; Holocene; Irano-Turanian vegetation; Peatland; PCA

\section{Introduction}

The area in west Asia that covers modern Turkey, the Caucasus and Iran is home to rich and highly diverse flora (Mittermeier et al., 2011; Frey et al., 1999; Zohary 1973). The Iranian northwest, in particular, has attracted the attention of a number of investigators who pursue the history of human activities in the region (van Zeist and Bottema 1977; Bottema 1986; Klein and Lacoste 1995; Djamali et al., 2009; Ponel et al., 2013; Ramezani et al., 2020) and its floral diversity (Zohary 1973; Assadi 1998; Ghahremaninejad et al., 2012). Understanding the relationship between climate, environmental and human factors that shaped the vegetation of the past is key to reconstructing the origin, history and trajectories of existing terrestrial ecosystems in this region (Birks 2012; Dearing 2006). Multiproxy palaeoecological studies are particularly helpful in developing a comprehensive framework of the forces and responses that drive environmental transformations over extended periods of time (Zacharyet al., 2010).

Among terrestrial environments, peatlands have shown great potential to preserve high-resolution archives of changes in palaeoecological conditions. They have been used to reconstruct abrupt changes in climatic and environmental conditions during the late Quaternary, particularly the Holocene, as well as the

${ }^{*}$ Correspondence: E. Ramezani, as above.

E-mail: e.ramezani@urmia.ac.ir human impact on natural vegetation (Barber 1981; Martini et al., 2006; Muller et al., 2008; van Geel and Mauquoy 2010; Naafs et al., 2017). Palaeoenvironmental investigations in peatlands using palynological and/or geochemical proxies have revealed the relationships between climate change, vegetation dynamics and human impact across western Asia, including the Iranian Plateau, during the Last Glacial period and the Holocene (Djamali et al., 2008; Kuzucuoğlu et al., 2011; Woodbridge and Roberts 2011; Ponel et al., 2013; Ramezani et al., 2020; Sharifi et al., 2015; Talebi et al., 2016).

A seminal palynological study based on the sediments of Lake Urmia in northwest Iran (Fig. 1a) was presented in Bottema (1986), in which the dominant vegetation and climate history of the area was reconstructed for the periods of the Late Glacial and the Holocene. The Lake Urmia pollen record from that study shows that the region was covered by steppe vegetation prior to $9000 \mathrm{BP}$, dominated by various Artemisia species. A relative increase in precipitation triggered foreststeppe development during the time interval of 9000-8000 вр. The present vegetation type in the area has been established since 7000 BP. Forest vegetation development in eastern Turkey and western Iran in the Early Holocene was partially delayed compared with the southwestern coastal areas of Asia (Wright et al., 1967; Roberts et al., 2001; Djamali et al., 2010). The eastern Mediterranean region experienced stronger precipitation seasonality than eastern Turkey and western Iran 

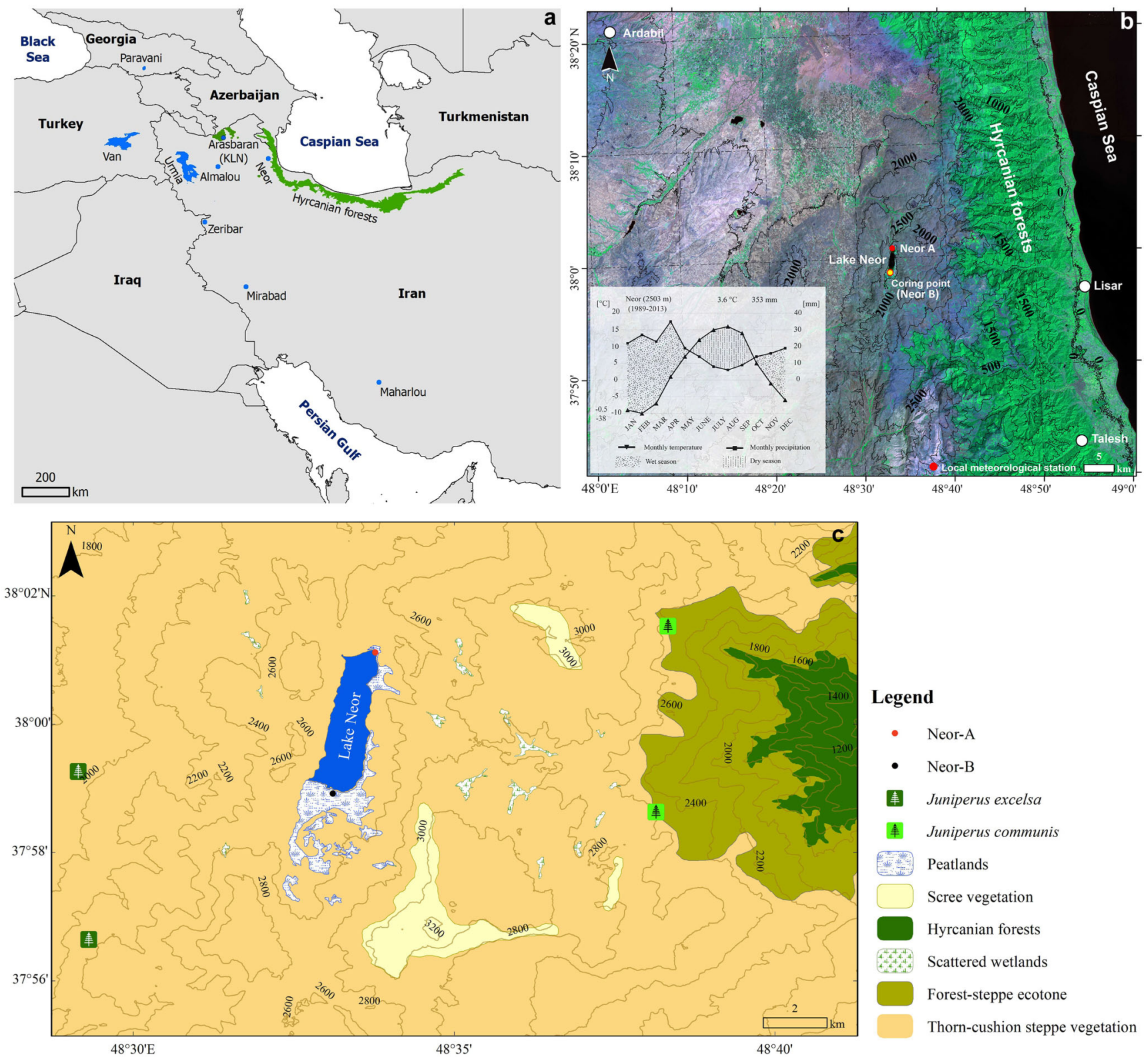

Figure 1. Geographical location of Lake Neor in northwestern Iran showing the position of other sites discussed in the text (a, b) and a closer view of the study area with the main regional vegetation types (c). The core studied by Sharifi et al., 2015 (not shown) was retrived 200 meters away to the east of Neor B. The map was produced using Landsat 8 (2019) natural colour composite. [Color figure can be viewed at wileyonlinelibrary.com].

over the Late Glacial and the Early Holocene, leading to an earlier establishment of forest vegetation in those areas (Roberts and Wright, 1993). A more recent study further expanded the vegetation and climate history of northwestern Iran to include the last glacial and interglacial cycles (cf. Djamali et al., 2008). According to this study, a steppe of Artemisia and Poaceae, in which Chenopodiaceae also played a major role, prevailed in northwestern Iran during both the penultimate and last glaciations. The vegetation succession at the transition of Late Glacial to Early Holocene in the area is represented by Hippophaë rhamnoides, Ephedra, Betula, Pistacia and finally Juniperus and Quercus.

In addition to the record from Lake Urmia, a number of palaeoecological studies have been carried out in the Lake Neor basin in northwestern Iran. Ponel et al., (2013) studied a $3 \mathrm{~m}$ long sedimentary core, covering the past 6500 years, from the northeastern corner of the lake for beetle assemblages of coprophilous and coprophagous species and pollen. These records that were also consistent with archaeological evidence showed that the early practice of cereal and Fabaceae cultivation and later fruit tree cultivation, e.g. Prunus, Juglans and Olea, was common around the highlands of the lake in the Talysh Mountains (Ponel et al., 2013).

Sharifi et al., (2015) recovered a $7.5 \mathrm{~m}$ core from the southwestern peripheral peatland of Lake Neor, approximately $200 \mathrm{~m}$ to the east of the Neor B core (not shown in Fig. 1), and using a high-resolution multiproxy approach, they reconstructed the aeolian input and palaeoenvironmental conditions of the region for the past 13000 years. The authors identified an abrupt transition from the Last Glacial to the Holocene followed by more favourable climatic conditions with increased moisture. The Early Holocene was a wet period during which brief periods of high atmospheric dust input had occurred around 8200-8000 and 7600-7400 cal a BP. The transition to the middle-late Holocene was found to coincide with the longer and more frequent dry periods, during which the northwestern region of Iran, including the Lake Neor area, experienced at least eight episodes of dry climate with high atmospheric dust content (see Fig. 5 in Sharifi et al., 2015). 
The study of the aeolian input to Neor during the Holocene has also revealed a shift in dust sources due to the southward migration of the Westerlies from the Younger Dryas to the Early Holocene (Sharifi et al., 2018). In order to investigate the aeolian effects on the deposition of high-altitude lacustrine basins in western Asia, Kazancı et al., (2016) used modern meteorological records and showed that the sedimentation of Lake Neor was affected by dust storms leading to a considerable amount of deposition of airborne particles. Aubert et al., (2017) also reconstructed the palaeohydrological and climatic history of Lake Neor from the end of the Late Glacial to the Middle Holocene (15 500-7500 cal a BP), identifying four main hydrological phases using subfossil chironomid and pollen assemblages from a core collected from the south of the lake.

The studies summarised above have examined the hydroclimatic changes and human activities at the end of the Late Glacial to the Early Holocene based on geochemical proxies, chironomid and pollen assemblages. A similar multiproxy hydroclimatic reconstruction is, however, missing for the Middle to Late Holocene of northwestern Iran. The aim of the present study is to build on prior investigations by looking at the potential influence of climatic fluctuations on vegetation in the highlands of northwestern Iran. We present a pollen record from the southern part of the lake to investigate human activities and vegetation changes based on the combined interpretation of pollen and geochemical-based results over the past 7000 years.

\section{Study area}

Neor $\left(37^{\circ} 55^{\prime}-38^{\circ} 01^{\prime} \mathrm{N}, 48^{\circ} 34^{\prime}-48^{\circ} 36^{\prime} \mathrm{E}\right.$; $2500 \mathrm{~m}$ a.s.I.) is a seasonally recharged freshwater lake in the Talysh (Talesh) Mountains in the western extension of the Alborz (Elborz) orogenic belt in northwestern Iran (Fig. 1). Lake Neor is the largest lacustrine basin in the high mountains of the Middle East (Kazancı et al., 2016). It is situated about $10 \mathrm{~km}$ to the west of the deciduous broadleaved Hyrcanian forest in a tectonic basin that formed during the Eocene due to the interaction of the Neor Fault and another fault in the western wing of the lake (Madadi et al., 2005). The lake surface area varies seasonally between 2.1 and $2.4 \mathrm{~km}^{2}$ (Madadi et al., 2005). The southern and southwestern banks of the lake consist of a peripheral peatland with an estimated surface area of $1.5-2 \mathrm{~km}^{2}$.
The primary moisture sources of the Lake Neor basin are systems that originate from the Mediterranean Sea and the Black Sea. Precipitation mainly occurs during the winter season through westerly storm tracks as part of the mid-latitude westerlies (Schiemann et al., 2009; Nagashima et al., 2011). Based on recent bioclimatic classification for Iran (Djamali et al., 2011), the climate of the area is Mediterranean continental. Climate data over a 23-year period from the Neor meteorological station indicates that the mean annual temperature and precipitation of Neor are $3.6{ }^{\circ} \mathrm{C}$ and $353 \mathrm{~mm}$, respectively (Fig. $1 \mathrm{~b}$ ). The annual number of freezing days is 128. The dry season extends from June to October and the average temperatures of the hottest (August) and coldest (February) months are 16.5 and $-10{ }^{\circ} \mathrm{C}$, respectively.

Lake Neor is strategically located in a region rife with diverse local microclimates due to drastic changes in elevation within relatively short distances. Physiognomically, Lake Neor is surrounded by mountain steppes, thorn-cushion plants, grasslands/meadows, cliffs and riparian vegetation types ranging in elevation between 1800 and $3200 \mathrm{~m}$ (see Fig. 1c). In terms of biogeography, the eastern area of the lake extends to the Hyrcanian forests in northern Iran, which is part of the Euro-Siberian phytogeographic region. The southern and western parts of the lake fall into the Irano-Turanian region (Ghahremaninejad et al., 2012; Alinezhad et al., 2017; Naqinezhad et al., 2021). Asteraceae, Poaceae, Brassicaceae, Fabaceae, Rosaceae, Caryophyllaceae and Ranunculaceae are the richest families of vascular plants of Lake Neor's steppes and surrounding ecosystems (Ghahremaninejad et al., 2012). The littoral wetlands surrounding the lake host an array of rare and protected vascular plants such as Sparganium emersum, Sparganium natans, Ranunculus peltatus and Utricularia minor. Figure 2 illustrates some of the main vegetation communities of the southern part of the lake during the growing season of spring and summer.

\section{Materials and methods}

\section{Coring}

An 8 m long core (Neor B; see Fig. 1b,c) was recovered during a lake lowstand in September 2008 using a Russian split-borer from the southwestern part of the wetland at $38^{\circ} 01^{\prime} \mathrm{N}$ and

Figure 2. The main vegetation communities in the marginal peatland of Lake Neor. Top left: aquatic vegetation at coring locaton; top right: extensive wet meadows surrounding the lake with large Carex tussocks; bottom left: grazing effects of local cattles in surrounding meadows of the lake; bottom right: a view of Lake Neor and its surrounding steppes. [Color figure can be viewed at wileyonlinelibrary.com].

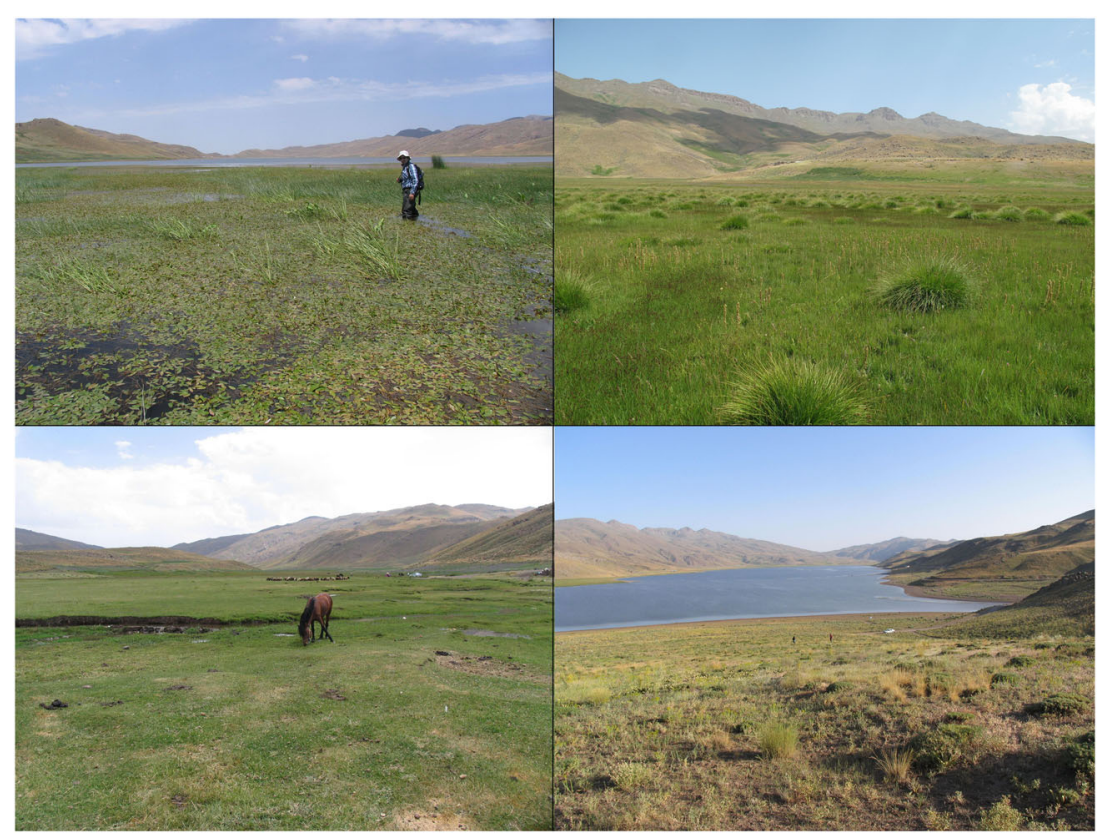


$48^{\circ} 34^{\prime} 23^{\prime \prime}$ E. The sediment was described by visual inspection and under stereomicroscope. The lower $3 \mathrm{~m}$ of the core were analysed and published by Aubert et al., (2017). Here we focus on the upper $5 \mathrm{~m}$ of the core.

\section{Chronology}

The chronology of the core is based on five accelerator mass spectrometry radiocarbon ages. Samples containing organic matter were processed at the Poznań Radiocarbon Laboratory for age determination. The radiocarbon ages were calibrated with Intcal13 calibration curve (Reimer et al., 2013) using the Clam package (Blaauw 2010) included in $\mathrm{R}$ version 3.0.1 (R Core Team 2012) at two standard deviations.

\section{Palynology}

Twenty-one subsamples were collected at $20 \mathrm{~cm}$ intervals along the core at the Institut Méditerranéen de Biodiversité et $d^{\prime}$ Ecologie (IMBE). Palynological sample preparation followed the standard method suggested by Fægri and Iversen (1989), which includes treatment with sodium hydroxide $(\mathrm{NaOH})$ followed by hydrochloric acid $(\mathrm{HCl})$, sieving with $160 \mu$ mesh, treatment with concentrated hydrofluoric acid (HF) and finally acetolysis. In order to calculate pollen concentrations (grains/g), Lycopodium tablets were added to the samples before processing (Stockmarr 1971). A CX31 Olympus light microscope was used for pollen identification and counting at $400 \times$, and for difficult pollen grains, 1000× magnification. Pollen and spores were identified and named $(M)$ : Moore et al., (1991), (B): Beug (2004) and (ZB): van Zeist and Bottema (1977) as well as the pollen reference slides of the Faculty of Natural Resources, Urmia University. Pollen diagrams were produced using Tilia software version 2.0.41 (Grimm 2015).

We refrain from using Amaranthaceae sensu APG IV (Chase et al., 2016) in this paper because of the paucity of Amaranthaceae sensu stricto in Irano-Turanian flora (cf. Dehghani et al., 2017).

We used the (Artemisia + Poaceae)/Chenopodiaceae ratio $((\mathrm{A}+\mathrm{P}) / \mathrm{C})$ as a moisture pollen index (cf. Shumilovskikh et al., 2016).

\section{Principal component analysis}

To obtain information regarding similar pollen composition among different pollen zones, as well as to determine which pollen taxa exhibited similar reactions in a pollen percentage diagram, detrended correspondence analysis (DCA) and principal component analysis (PCA) were conducted using CANOCO 4.5 software based on the square-root-transformed pollen percentage data (calculated on the basis of the arboreal pollen (AP) + nonarboreal pollen (NAP) pollen sum; see Palynological data, below). The DCA showed that the pollen percentage data have a predominantly linear structure, resulting in the use of a linearbased PCA (ter Braak 1987). In the PCA, the data were speciescentred. Furthermore, the variables $A P, N A P,(A+P) / C$ and charcoals were passively projected in the diagram.

\section{$X R F$ core scanning}

The analytical procedures for measuring the relative abundances of elements in the peat core were similar to those described in Sharifi et al., (2015). Briefly, down-core variations of the relative elemental abundances of $\mathrm{Al}-\mathrm{U}$ were measured using an AVAATECH XRF core scanner in the Palaeoclimatology Lab in the Marine Geoscience Division, Rosenstiel School of Marine and Atmospheric Science (MGS-RSMAS). All core sections were scanned three times $(10 \mathrm{kV}, 1000 \mathrm{~mA}$, no filter;

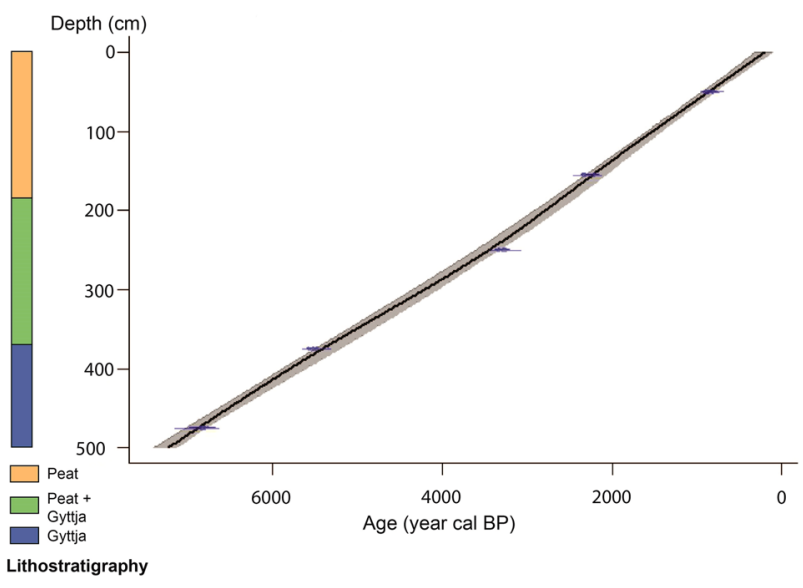

Figure 3. Lithostratigraphy and age-depth model for the studied peat core from Lake Neor. The age-depth model was developed with the CLAM software (Blaauw 2010) using a smooth spline - interpolated method and the "IntCal13" 14C calibration curve (Reimer et al., 2013). [Color figure can be viewed at wileyonlinelibrary.com].

$30 \mathrm{kV}, 1000 \mathrm{~mA}, \mathrm{Pd}$ filter; and $50 \mathrm{kV}, 1000 \mathrm{~mA}, \mathrm{Cu}$ filter) to acquire the range of elements reported here. The surface area was irradiated for $20 \mathrm{~s}$ (for $10 \mathrm{kV}$ and $30 \mathrm{kV}$ passes) and $30 \mathrm{~s}$ (for $50 \mathrm{kV}$ pass) of integration time at $5 \mathrm{~mm}$ intervals using a window $5 \mathrm{~mm}$ high by $12 \mathrm{~mm}$ wide. The Canberra WinAxil software with standard software settings and spectrum-fit models were used to process the raw XRF spectra. The elemental abundances are reported as the intensity of each element in counts per second (cps). The data were calibrated using runs of a JR-1 standard (Geological Survey of Japan) before and after each analysis session.

\section{Total organic content}

The total organic content (TOC) data are cited from Sharifi et al., (2015). In short, 400 subsamples were analysed along the $7.5 \mathrm{~m}$ core. Inorganic carbon was removed from homogenised samples by acidification using $10 \% \mathrm{HCl}$ according to the procedure described by Hedges and Stern (1984). Between 2 and $15 \mathrm{mg}$ of pretreated sample was transferred into precleaned tin cups and total organic carbon was measured with a Thermo Scientific Flash $2000 \mathrm{CHN}$ analyser at the Virginia Institute of Marine Science (VIMS).

\section{Results \\ Lithostratigraphy and ${ }^{14} \mathrm{C}$ chronology}

The core segments appeared homogeneously composed of organic sediment with occasional variations in texture. The core consisted of dark gyttja at the bottom section, a mixture of dark gyttja and peat in the middle section between 2 and $3.75 \mathrm{~m}$, and fine peaty material in the uppermost $2 \mathrm{~m}$ (Fig. 3). No mineral fraction was visible with the naked eye along the core.

The age model for the core in this study, based on the calibrations described above, is presented in Fig. 3 and encompasses the Middle Holocene (ca. $6700 \mathrm{yr}$ cal BP) to Late Holocene (Table 1).

The accumulation rate calculated based on the same age-depth model ranged between 1.2 and $1.7 \mathrm{~mm} / \mathrm{a}$.

\section{Inorganic proxy record}

Down-core abundances of refractory conservative elements $(\mathrm{Ti}, \mathrm{Al})$, mobile elements $(\mathrm{Ba})$, and redox-sensitive elements 
(Fe, Mn, $\mathrm{V}$ and Mo) measured by XRF-scanning at an average resolution of $\sim 7$ years are presented in Table S1. A previous study by Sharifi et al., (2015) showed that the ombrotrophic nature of the peat has been sustained throughout the past 13 300 years. Considering the absence of any significant riverine input to this high-altitude peat mire, the authors suggested that the elevated intensities of lithogenic elements (e.g. Ti and Al) correspond to the deposition of atmospheric mineral dust over the study area. They also concluded that mineral dust particles have not been mobilised since deposition, based on the high correlation between the abundances of refractory conservative elements and both mobile and redox-sensitive elements. As suggested by Sharifi et al., (2015, 2018), we used down-core abundances of $\mathrm{Ti}$ as a proxy for dust input during the dry period (Fig. 7). Down-core variation in Ti (Fig. 7) shows at least three periods of prolonged high $\mathrm{Ti}$ abundances during 6300-5200 cal a BP, 4500-2900 cal а BP, and 1300-present. Elemental ratios such as $\mathrm{Mo} / \mathrm{V}, \mathrm{Mn} / \mathrm{Al}, \mathrm{Mo} / \mathrm{Al}, \mathrm{Ba} / \mathrm{Al}$ and $\mathrm{Fe} / \mathrm{Al}$ are widely used as palaeo-redox proxies to reconstruct fluctuations in lake levels (Calvert and Pedersen 2007; Martinez-Ruiz et al., 2015; Rodrigo-Gámiz et al., 2014). Higer $\mathrm{Mo} / \mathrm{V}, \mathrm{Mn} / \mathrm{Al}, \mathrm{Mo} / \mathrm{Al}, \mathrm{Ba} / \mathrm{Al}$ and $\mathrm{Fe} / \mathrm{Al}$ ratios are correlated with lower Ti abundances (Fig. 7).

\section{Palynological data}

The palynological data are presented in the following two forms:

i. percentage values relative to pollen sum, i.e. total count for AP and NAP types (excluding wetland types) (Fig. 4).

ii. concentration values for a selection of taxa (Fig. 5).

Pollen assemblage zones (PAZs) were identified using CONISS cluster analysis (Grimm 1987). On this basis, the pollen diagrams were divided into three zones and four subzones (Figs. 4 and 5). In the following, we describe the distribution of the above PAZs separately as a function of time to show the terrestrial upland vegetation and local hydrological change.

\section{PAZ NEOR-I $(460-290 \mathrm{~cm} ; 6710-4030 \mathrm{cal}$ а вр)}

This zone may be split into two subzones based on CONISS cluster analysis, i.e. NEOR-la $(460-420 \mathrm{~cm} ; 6710-6150 \mathrm{cal}$ а вP) and NEOR-Ib (420-290 cm; 6150-4030 cal a вP). The characteristic feature of the first subzone is rather high values of AP types, particularly Quercus, Fagus and Salix (Fig. 4). Other important, albeit less frequent pollen taxa include Betula, Celtis, Carpinus type, Ulmus and Ephedra distachya-type. Artemisia and Chenopodiaceae are the predominant pollen types across the studied record. Other mentionable NAP types are Cirsium, Thalictrum, Ranunculus and Caryophyllaceae. With values up to 8.4, the $(\mathrm{A}+\mathrm{P}) / \mathrm{C}$ ratio culminates in this subzone. Of wetland types, Cyperaceae is the main constituent. Less frequent aquatic types are
Lemna minor, Callitriche stagnalis, Sparganium erectum and Lysimachia vulgaris.

The next subzone is mainly characterised by decreased AP types and an increase of Poaceae and Chenopodiaceae. $(\mathrm{A}+\mathrm{P}) / \mathrm{C}$ ranges between 1.5 and 4.6. Cyperaceae substantially increases and remains the most abundant wetland types throughout the record.

Concentration values of the main constituents of the record, Artemisia, Chenopodiaceae, Poaceae and Cyperaceae, show prominent peaks in NEOR-la (Fig. 5).

\section{PAZ NEOR-II $(290-150 \mathrm{~cm} ; 4030-2215 \mathrm{cal}$ a $\mathrm{BP})$}

This zone was divided into two subzones, NEOR-Ila $(290-230 \mathrm{~cm}$; 4030-3150 cal a BP) and NEOR-Ilb (230-150 cm; $3150-2215 \mathrm{cal}$ a BP). The main features of the first subzone are the raised values of Chenopodiaceae (Fig. 4) and relatively low values of Artemisia and Poaceae $((A+P) / C$ ratios: 0.8-1.6), which are also observed in the pollen concentration diagram (Fig. 5).

The subzone NEOR-Ilb is characterised by the predominance of Artemisia and Poaceae $((A+P) / C$ ratios: 3.3-4). Other notable features of this section of the record include a slight increase of Quercus, and the continuous, though low value, curves of Carpinus-type and Betula. We see substantial values of Artemisia, Chenopodiaceae, Poaceae and Cyperaceae at the beginning of the subzone in the concentration diagram. From this point up to the end of the record, the concentration values of all groups of pollen types decrease dramatically.

\section{PAZ NEOR-III $(150 \mathrm{~cm}$ to the core top; $2215 \mathrm{cal} \mathrm{a}$ $B P$ to present)}

With the exception of a small peak in the middle, the AP curve represents its lowest values throughout the record. Compared with the former zones, this section of the record shows the lowest diversity of AP taxa; Quercus, Fagus and Ephedra distachya-type to name a few. Artemisia and Poaceae decline relative to the previous subzone, whereas Chenopodiaceae produces a prominent peak in the lower half and remains the major constituent of the entire zone (Fig. 4). Another notable feature of this zone is the significant peak of Apiaceae in the lowermost spectrum, which is followed by a rise of Caryophyllaceae and, to a lesser extent, Fabaceae. Overall, NAP types diversify towards the upper spectra of this zone and of this group, Centaurea solstitialis and Plantago lanceolata types should be noted. The $(A+P) / C$ ratios show values between 0.5 and 1.9, respectively; a notable decline relative to the previous zone. Another characteristic feature of this zone is the prominent peaks of microscopic charcoals in its lower half. Cyperaceae peaks at the beginning of the zone but gradually declines thereafter. Most other wetland pollen types disappear towards the surficial samples in this terminal zone.

Table 1. Radiocarbon dates and calibrated ages for peat core from Lake Neor.

\begin{tabular}{|c|c|c|c|c|c|}
\hline Laboratory code & Depth $(\mathrm{cm})$ & Material & $\begin{array}{c}\text { Conventional }{ }^{14} \mathrm{C} \text { age } \\
(\mathrm{RCYBP})\end{array}$ & $\begin{array}{c}\text { Midpoint calibrated age }(\mathrm{a} \mathrm{BP}) \pm 2 \sigma \\
\text { error }\end{array}$ & $\begin{array}{l}\text { Accumulation rate } \\
\qquad\left(\mathrm{mm} \mathrm{a}^{-1}\right)\end{array}$ \\
\hline Poz-SE-B-11 & 52.5 & Peat bulk & $920 \pm 30$ & $901 \pm 66$ & 1.7 \\
\hline Poz-SE-B-10 & 152.5 & Peat bulk & $2285 \pm 30$ & $2186 \pm 114$ & 1.3 \\
\hline Poz-SE-B-9 & 252.5 & $\begin{array}{c}\text { Peaty } \\
\text { gyttja bulk }\end{array}$ & $3085 \pm 30$ & $3443.5 \pm 105.5$ & 1.2 \\
\hline Poz-SE-B-8 & 372.5 & Peat bulk & $4775 \pm 35$ & $5451.5 \pm 91.5$ & 1.7 \\
\hline
\end{tabular}



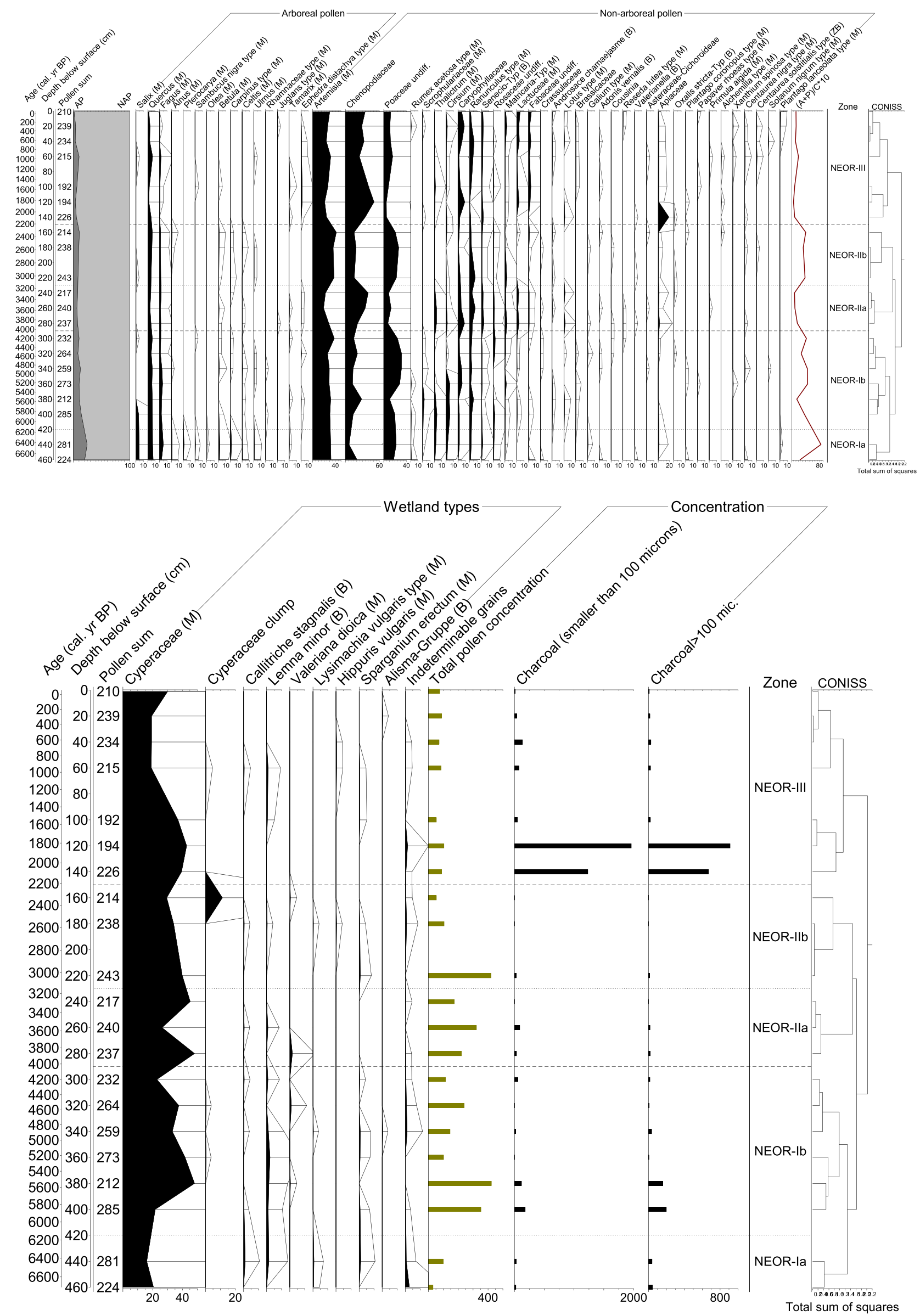

Figure 4. Pollen percentage diagram for the Neor site showing terrestrial (AP+NAP) and wetland types. The actual values are displayed in black silhouette curves with a 10-time exaggeration (depth bars). For better visualization, the (A+P)/C ratios are also exaggerated 10-times. [Color figure can be viewed at wileyonlinelibrary.com]. 


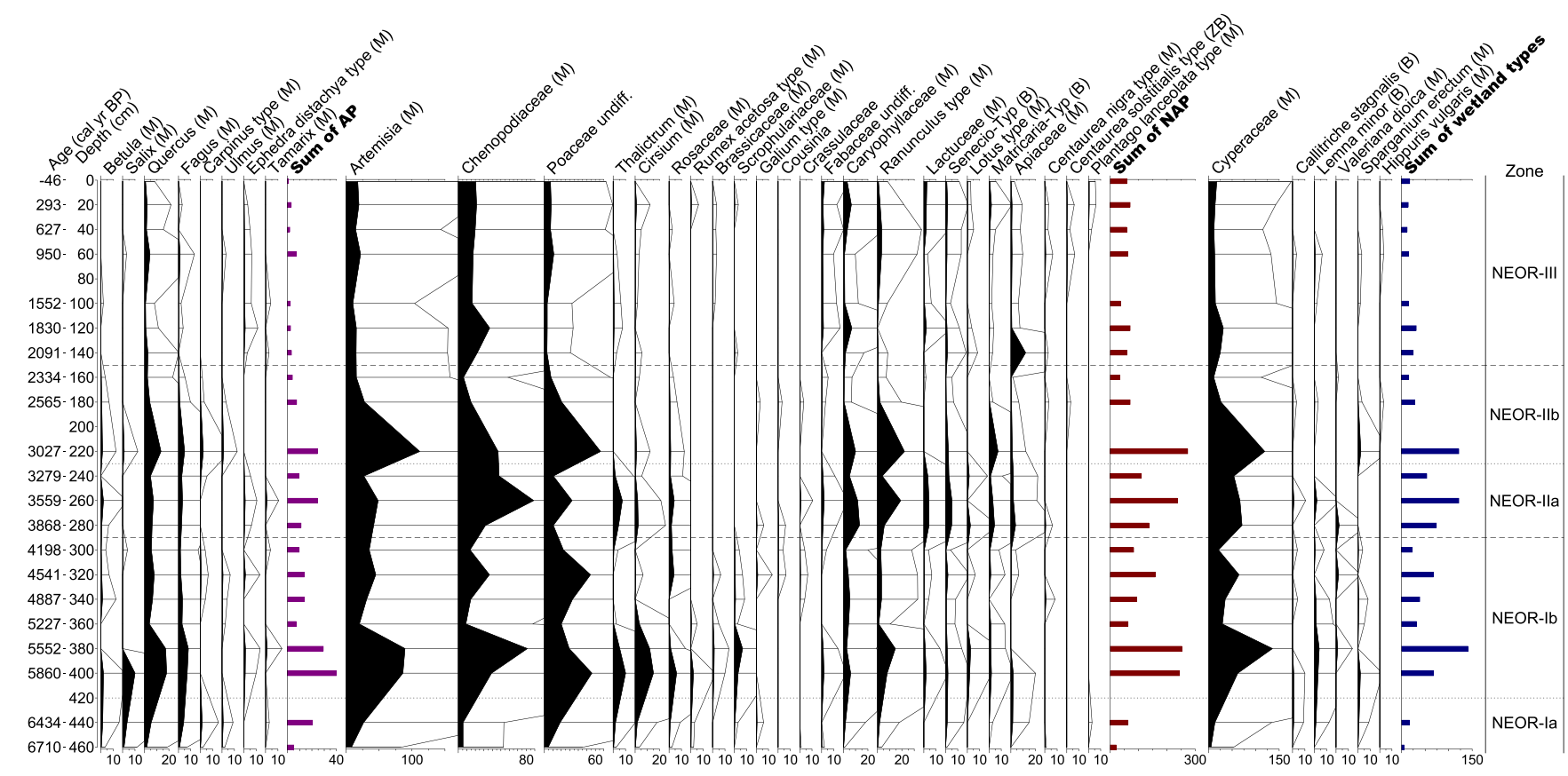

Figure 5. Pollen concentration (grains/g per 100) diagram for Lake Neor. [Color figure can be viewed at wileyonlinelibrary.com].

\section{Principal component analysis}

Together, the first two principal components explained $43.9 \%$ of the variation in the pollen data (axis 1: $34 \%$; axis 2: 9.9\%). The first axis of the PCA indicates a humidity gradient with opposing variables in two sides of the diagram (Fig. 6). The second axis is well represented by such pollen types as Thalictrum and Cirsium along with a number of disturbance indicator pollen types, such as Centaurea solstitialis, Plantago lanceolata, Euphorbia, Solanum nigrum and Carpesium. Cyperaceae are important on both first and second axes (see Discussion).

\section{Discussion}

The climatic and/or anthropogenic factors that exerted control over vegetation and hydrological changes in the highlands of northwestern Iran since the Mid-Holocene can be better understood with a multiproxy approach using a combination of pollen and geochemical data. Redox-sensitive and mobile (Mo, Mn, V, Fe and Ba) elements in aquatic environments behave differently under oxic and suboxic-anoxic conditions and form soluble/insoluble species in the water column (Algeo and Maynard 2004; Calvert and Pedersen 1993). The relative abundances of these elements compared with $\mathrm{Al}$, which is primarily of terrigenous origin, (Martinez-Ruiz et al., 2015; Gámiz et al., 2014) can be used as a proxy for water availability or wet/dry conditions in lake settings such as Neor. Contrasting the geochemical proxies with variations in pollen assemblages that represent predominantly wet conditions to those that thrive under drier climate suggest four major phases in the evolution of the hydroenvironment and landscape of the Lake Neor area since the Mid-Holocene (Fig. 7). These phases are defined by visual comparison of the variations in all environmental proxies. Admittedly, the age model established based on 19 radiocarbon dates in Sharifi et al., (2015) and this study (calibrated based on five radiocarbon dates) on the same depth interval of two different core locations from Lake Neor show some discrepancies in the TOC, $\delta \mathrm{D}$ and carbon accumulation rate data due to differences in age models. We therefore recognise that the apparent lag between plant response to climate variability may in part be due to age-model differences between the current pollen dataset and the geochemical data from Sharifi et al., (2015). This, however, does not impact our interpretation of both datasets on a millennial time scale.

\section{Interpretation of the pollen ratios}

In a steppe environment such as the Lake Neor basin, AP indicates long-distance transport, whereas non-arboreal pollen (NAP) must reflect the vegetation composition of the surrounding landscape (i.e. regional pollen deposition, Janssen 1973). In the search for an appropriate bioclimatic index in such environmental conditions, the ecological characteristics of the main pollen types (respective plant taxa) are shown to be particularly helpful (El-Moslimany 1990).

The co-occurrence of Poaceae and Artemisia species in the modern steppes surrounding Lake Neor on one hand, and a more or less parallel trend in the frequencies of their corresponding pollen types in the fossil pollen record (Fig. 4) on the other, may point to their largely similar ecological requirements. Characterised by shallow root systems, grasses grow vigorously in climates with summer rainfall (El-Moslimany 1990). In addition, several orophytic Artemisia species, including $A$. haussknechtii, A. persica and $A$. austriaca, flourish in wetter localities in northwestern Iran (Zavvar et al., 2017; Ramezani et al., 2020). High pollen frequencies of Chenopodiaceae in pollen diagrams may stem from xeric, halophytic or even ruderal communities (Dehghani et al., 2017). As no halophytic chenopods occur in the area of Lake Neor (Ghahremaninejad et al., 2012; Alinezhad et al., 2017), the high pollen proportion of Chenopodiaceae in our pollen record can arguably be interpreted as the prevalence of dry climatic conditions that may have coincided with anthropogenic disturbances. We conclude that the $(A+P) / C$ ratio positively correlates with climatic condition (i.e. higher ratios correlate with wetter periods and vice versa).

\section{The interval of 6710-6200 cal a BP}

The relatively high diversity and abundances of AP types (Fig. 4), in particular of those attributable to Quercus, Fagus, Carpinus and Betula and, to a lesser extent, Alnus, Ulmus and Pterocarya, 


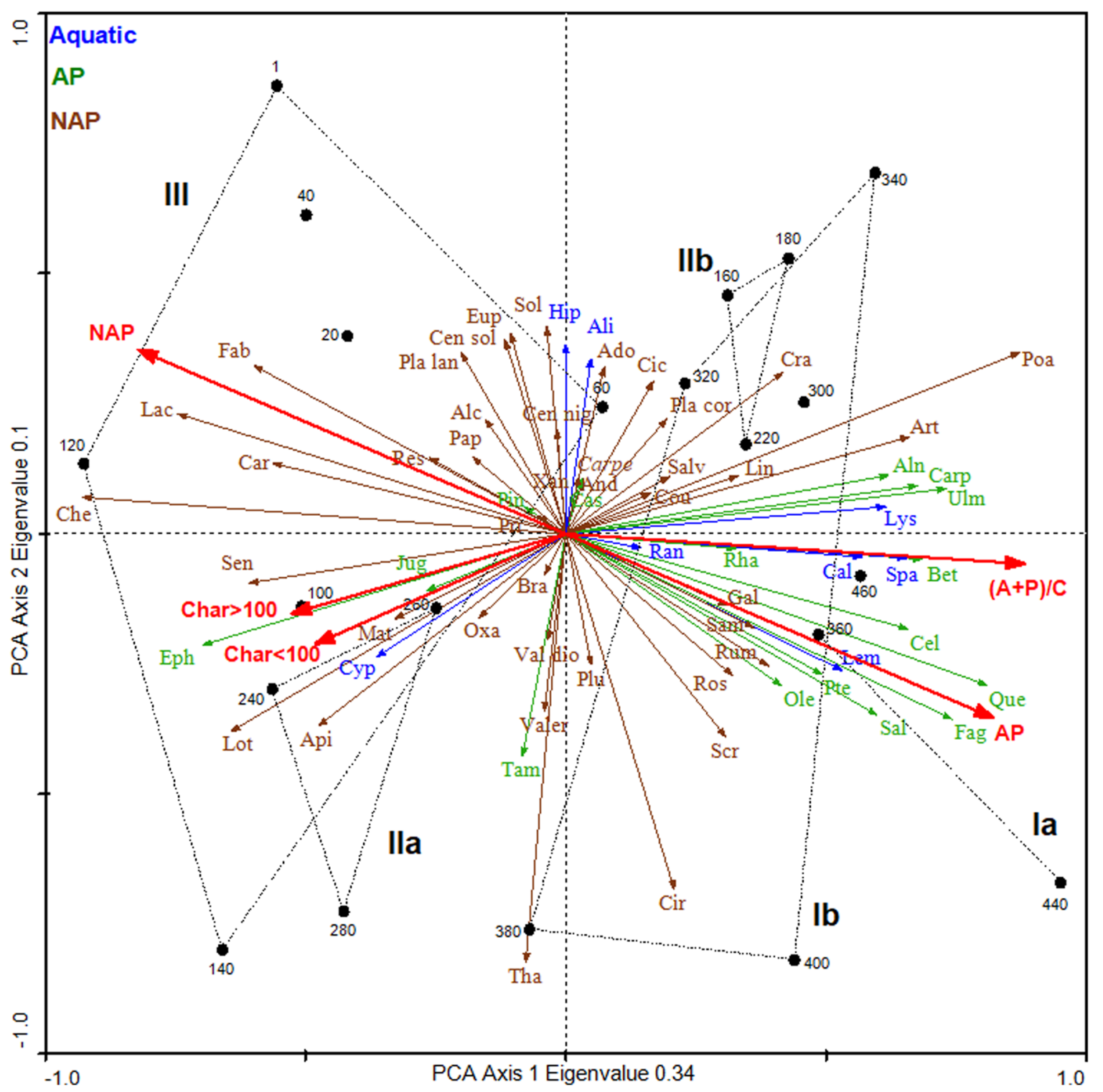

Figure 6. PCA (Principal Component Analysis) of pollen data on the collected sample (different depths) of the core Neor B. Numbers and colours indicate samples of different depths and species groups, respectively. Samples are classified in different zones (I-III). The variables AP, NAP, (A+P)/C and charcols were passively projected in the diagram. Ado: Adonis vernalis, Alc: Alchemilla, Aln: Alnus, Ali: Alisma, And: Androsace chamaejasme, Api: Apiaceae, Art: Artemisia, Bet: Betula, Bra: Brassicaceae, Cal: Callitriche stagnalis, Carpe: Carpesium, Carp: Carpinus, Car: Caryophyllaceae, Cas: Castanea sativa, Cel: Celtis, Cen nig: Centaurea nigra, Cen sol: Centaurea solstitialis, Che: Chenopodiaceae, Cic: Cichorioideae, Cir: Cirsium, Cou: Cousinia, Cra: Crassulaceae, Cyp: Cyperaceae, Eph: Ephedra distachya, Eup: Euphorbia, Fab: Fabaceae, Fag: Fagus, Gal: Galium, Hip vul: Hippuris vulgaris, Jug: Juglans, Lac: Lactuceae, Lem: Lemna minor, Lin: Linum, Lot: Lotus, Lys: Lysimachia vulgaris, Mat: Matricaria, Ole: Olea, Oxa: Oxalis stricta, Pap: Papaver rhoeas, Pin: Pinus, Pla cor: Plantago coronopus, Pla lan: Plantago lanceolata, Plu: Plumbaginaceae, Poa: Poaceae, Pri: Primula algida, Pte: Pterocarya fraxinifolia, Que: Quercus, Ran: Ranunculus, Res: Reseda lutea, Rha: Rhamnaceae, Ros: Rosaceae, Rum: Rumex acetosa, Sal: Salix, Salv: Salvia verticillata, Sam: Sambucus nigra, Scr: Scrophulariaceae, Sen: Senecio, Sol: Solanum nigrum, Spa: Sparganium erectum, Tam: Tamarix, Tha: Thalictrum, Ulm: Ulmus, Val dio: Valeriana dioica, Valer: Valerianella, Xan: Xanthium spinosum. [Color figure can be viewed at wileyonlinelibrary.com].

during this period refer to their long-distance transport most likely from the Hyrcanian region, $10 \mathrm{~km}$ east of the lake. However, considering the pollen production and dispersal properties of the above taxa (Djamali et al., 2008; Ramezani et al., 2013), one may conclude that the forest stands comprising these trees were likely distributed closer to the Neor site than in modern times. At the same time, relatively high values of Salix pollen may be interpreted as the expansion of willows (Salix spp.) on the southern banks of Lake Neor or along a palaeo-gallery forest south of the lake. Potentially closer expansion of the Hyrcanian forests in this period may suggest a wetter-than-present climate for the Lake Neor basin and its surrounding areas. This argument is further supported by the low values of Chenopodiaceae and the high $(\mathrm{A}+\mathrm{P}) / \mathrm{C}$ ratio during this time (see Fig. 4). Furthermore, the relative abundances of pollen types attributable to aquatic plants such as Lemna minor, Sparganium spp. (e.g. S. erectum) and Callitriche spp. (Fig. 4) suggest a higher water table in this marginal part of the lake during the Mid-Holocene. With a slight difference in timing, which, as discussed above, may be due to differences in the age model between the two cores, the geochemical proxy data show low abundances of $\mathrm{Ti}$ and relatively high ratios of $\mathrm{Mo} / \mathrm{V}, \mathrm{Mn} / \mathrm{Al}$ and $\mathrm{Mo} / \mathrm{Al}$. These ratios correlated with high TOC percentages, more negative $\delta \mathrm{D}$ values and higer carbon accumulation rates from Sharifi et al., (2015) (Fig. 7), all suggesting a rather wet period for this part of the record. The inferred wet period is supported by the PCA analysis, where the high values of AP, Artemisia, Poaceae and $(\mathrm{A}+\mathrm{P}) / \mathrm{C}$ on the left side of the diagram (Fig. 6) indicate a humid period for the subzone NEOR-la, which is further characterised by the occurrence of local aquatic taxa. Pollen records from the eastern Mediterranean (Rossignol-Strick 1995, 1999) suggest that a wet period prevailed from 9000 to $6000 \mathrm{cal}$ a BP. Speleothem $\delta^{18} \mathrm{O}$ 


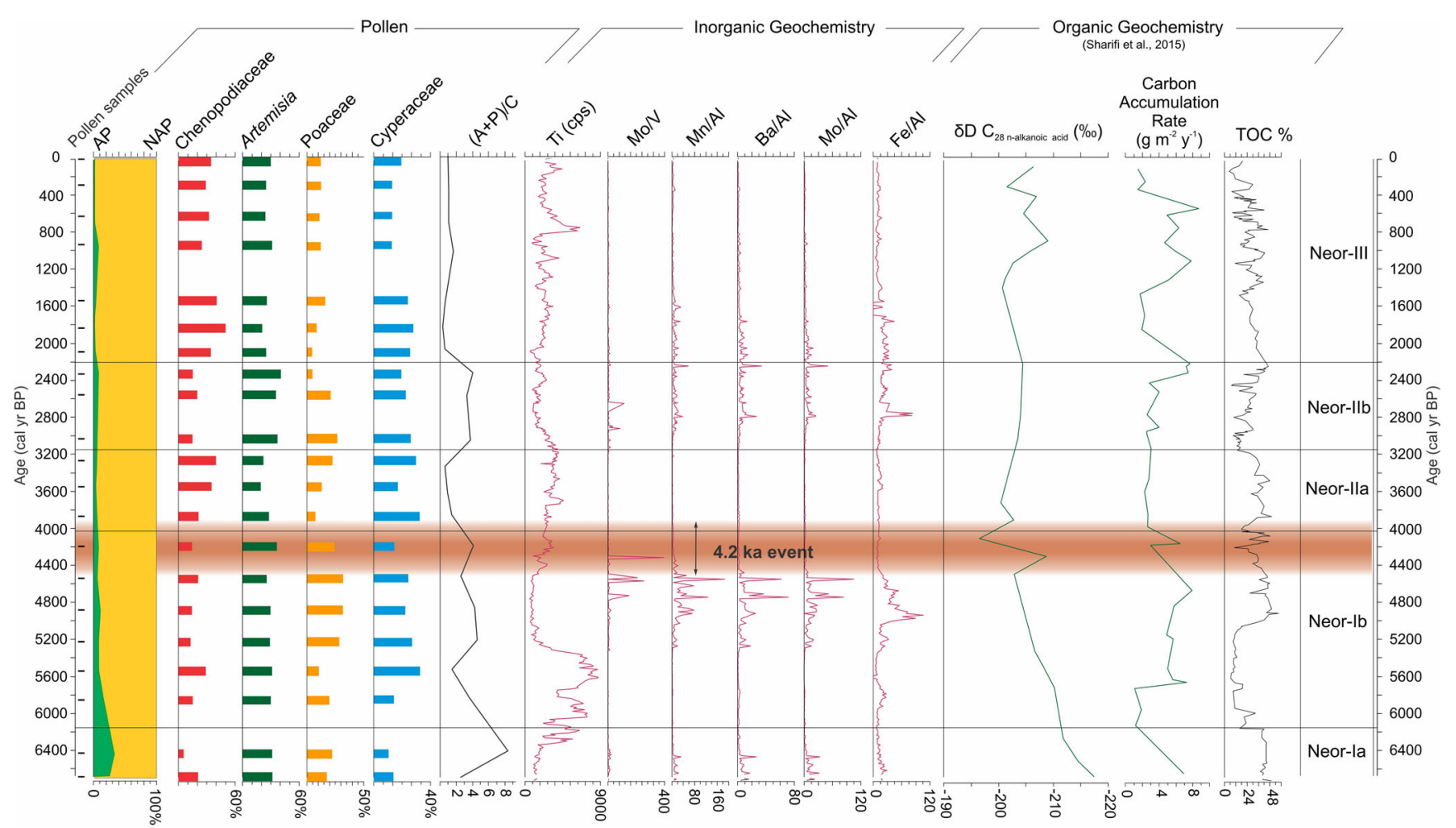

Figure 7. Palaeoecological data coordination: pollen and geochemical records of Lake Neor core. [Color figure can be viewed at wileyonlinelibrary.com].

values from the Soreq cave in Israel also revealed several short wet periods, 20 to 100 years long, from 6800 to $6100 \mathrm{cal}$ a BP (Bar-Matthews et al., 2003; Bar-Matthews and Ayalon, 2011).

\section{The interval of $6200-5200 \mathrm{cal}$ a $B P$}

This interval is characterised by decreased AP values and increased Chenopodiaceae along with lowered $(A+P) / C$ ratios (Fig. 4). This is largely in line with the geochemical data (Fig. 7). With the exception of three distinctly low intervals, the $\mathrm{Ti}$ abundances remain at the highest levels observed during the entire record, whereas $\mathrm{Mo} / \mathrm{N}, \mathrm{Mn} / \mathrm{Al}, \mathrm{Ba} / \mathrm{Al}$ and $\mathrm{Mo} / \mathrm{Al}$ drop to near background levels along with a substantial decline in TOC percentages and carbon accumulation rates. The $\delta \mathrm{D}$ values are also trending toward less negative values. Based on the PCA analysis, the values of NAP, charcoal particles and dry habitat indicators such as Ephedra distachya-type and Chenopodiaceae show high values on the left side of the first PCA axis (Fig. 6). The data accordingly suggest a relatively prolonged period of dry climatic conditions for this interval. We postulate that the higher percentages of Cyperaceae could correspond to a dry climate, where the resulting low lake level and exposure of marginal lands might have led to the expansion of sedge vegetation. With that said, based on the geochemical data, this dry period is expected to have been interrupted by three short wet periods, which correlates well with the eastern Mediterranean record from the Soreq cave (Bar-Matthews and Ayalon 2011; Sharifi et al., 2015). A severe 600 year-long drought would have persisted in western Iran centred at around $5500 \mathrm{cal}$ a BP according to Stevens et al., (2006), possibly correlating to the inferred dry period in the Lake Neor region.

\section{Between 5200 and $4450 \mathrm{cal} \mathrm{a} \mathrm{BP}$}

The Lake Neor basin experienced wetter conditions based on a small rise in AP values, which was also accompanied by increased $(A+P) / C$ ratios along with prominent peaks of
$\mathrm{Mn} / \mathrm{Al}, \mathrm{Ba} / \mathrm{Al}, \mathrm{Fe} / \mathrm{Al}$, and an increase in $\mathrm{TOC}$ and carbon accumulation rates, as well as low values of $\mathrm{Ti}$ abundances (Fig. 7). The remarkable expansion of Cyperaceae and Poaceae (Fig. 4) may indicate the expansion of the peatland during this time interval. Robinson et al., (2006) proposed a MidHolocene wet phase around $5000 \mathrm{cal} \mathrm{a} \mathrm{BP}$ in the Levant. Also, the study of sediment cores from the Dead Sea shore shows a short wet interval at $5100 \mathrm{cal}$ а ВP (Migowski et al. 2006). It is worth mentioning that the observed transition in regional vegetation (i.e. the rise of chenopods and decreased $(A+P) / C$ ratio at the boundary of pollen zones NEOR-Ib and NEOR-Ila; see Fig. 4) took place some time between 4300 and $3800 \mathrm{cal}$ a BP, a time interval known as the 4.2 ka event (Fig., 7). This time interval is also marked by the rapid change in $\delta \mathrm{D}$ values, indicating a shift toward less negative values (drier conditions). Following a recent formal subdivision of the Holocene into Greenlandian, Northgrippian and Meghalayan stages/ages (cf. Walker et al., 2018), the 4.2 ka event has been considered as "a time stratigraphic marker horizon for defining the base of the Meghalayan Stage/Age" (Walker et al., 2018). In the midand low latitudes, this event is frequently associated with a marked aridification phase, referred to sometimes as the 4.2-3.9 ka BP megadrought (Weiss 2016; Walker et al., 2019). The collapse of the Akkadian Empire in Mesopotamia and the Early Bronze Age settlements in Anatolia appear to relate to a shift toward a remarkable dry climate (Cullen et al., 2000; Weiss 2016). However, no evidence for a severe drought has been detected for this time in the Lake Zeribar and Lake Mirabad records in western Iran (Stevens et al., 2006), possibly due to the relatively low resolution of these studies.

\section{The interval of $4030-3150 \mathrm{cal}$ a $B P$}

The low values of AP types and Artemisia, significant increase of Chenopodiaceae and substantial decrease of $(A+P) / C$ ratios (Figs. 4,7 ) associated with the rise of $\mathrm{Ti}$ abundances and exceedingly low values of palaeo-redox proxies all confirm the 
prevalence of arid conditions for this period. This notion is supported by low values $\left(2.3-3.0 \mathrm{~g} \mathrm{C} \mathrm{m}^{-2} \mathrm{a}^{-1}\right)$ of carbon accumulation rates during this time frame (Fig. 7). Based on decreased values of Quercus pollen along with increased values of $\delta^{18} \mathrm{O}$, a rise in the $\mathrm{Mg} / \mathrm{Ca}$ ratio and higher values of charcoal, Wick et al., (2003) propose for eastern Turkey (the Lake Van area) increased aridity for the period 4000-2100 cal a BP. The authors, however, do not exclude the role of human impact. A cooling climate spanning the period 4000-3000 cal a BP in the Tsalka area (lower Javakheti, Georgia), could have resulted in a lowered timberline and the replacement of the oak savanna by a coniferous association of pine and fir (Connor and Sagona 2007).

\section{The interval of $3150-2215 \mathrm{cal}$ a $B P$}

This time period is characterised by significant values of Artemisia, a substantial decline in Chenopodiaceae and rather high values for $(\mathrm{A}+\mathrm{P}) / \mathrm{C}$ ratios in pollen percentage and concentration diagrams (Figs. 4, 5). A notable decrease in aeolian input ( $\mathrm{Ti}$ abundances) during the period 2900-2200 cal a BP, which was accompanied by increased palaeo-redox proxies and an increasing trend in the values of TOC $\%$ and carbon accumulation rates (Fig. 7; see also Fig. 3 which shows more organic/peat content) all suggest a rather wet period. In the Lake Maharlou basin, southwestern Iran, Brisset et al., (2018) suggest for the period 3800-2000 cal a BP a relatively high terrigenous input into the lake interpreted as an overall positive hydrological balance, corresponding to higher river flow and lower water loss through evaporation. This time frame was similarly recorded as a wet period in Lake Tecer, central Turkey (Kuzucuoğlu et al., 2011).

In contrast, most records from the eastern Mediterranean propose a dry climate for this interval (e.g. Roberts et al., 2001, 2008; Schilman et al., 2001; Wick et al., 2003; Kaniewski et al., 2008; Ocakoğlu et al., 2016; Ramezani et al., 2020). Nevertheless, palynological study from the southern Caucasus (Messager et al., 2013; cf. Lake Paravani in Fig. 1a) reports a significant vegetation change between 3200 and 2000 cal а вр. This period corresponds to the decline of Abies and Pinus and the progressive expansion of Picea, a deforestation phase and expansion of steppe vegetation attributable to an arid climate and human impact. Details, therefore, remain unclear when comparing biological and geochemical datasets and require more in-depth comparison using closely comparable age models to resolve.

\section{The interval of $2215 \mathrm{cal}$ a вP to present}

The past 2200 years are charactersied by declining values of Quercus pollen and the scarcity of most AP types; while Chenopodiaceae and Ephedra distachya-type reach their maximum values throughout the entire record (Fig. 4). Ephedra distachya-type pollen is considered as an indication of dry climatic conditions (Prentice et al., 1996; Wick et al., 2003; Zhao et al., 2012; Ramezani et al., 2020). This period coincides with rather frequent episodes of high Ti abundances, low values of palaeo-redox proxies, more fluctuations in $\delta \mathrm{D}$ values, carbon accumulation rates and TOC\% (Fig. 7), suggesting the recurrence of a dry climate in the Neor Lake basin area as was also proposed for the Arasbaran highlands in northwestern Iran (see Fig. 8). Wick et al., (2003) link the cold and arid conditions of eastern Anatolia over the period 2200-1500 cal a BP to low sun activity which could have increased the need for plant utilisation for energy and heat production. This may have driven the vegetation toward drought-tolerant species, which are among the secondary destructive elements (cf. Zohary 1973). We may accordingly ascribe the prominent peaks of charcoal particles during 2200-1800 cal a BP to successive local fires, which were likely human-induced.

Reconstructing the Late Holocene vegetation and climate history of the area southwest of Lake Urmia (Talebi et al., 2016), relatively cold and arid conditions along with fluctuating lake water levels and development of steppe vegetation have been proposed for the period between 2500 and $1500 \mathrm{cal} \mathrm{a} \mathrm{BP.} \mathrm{In} \mathrm{a}$ palynological study in the Arasbaran area, northwest of Ardabil Province (Fig. 1a), Ramezani et al., (2020) reported the potential for a severe drought, with the regional prevalence of steppe-like vegetation for the period 1400-1020 cal а вр (see also Fig. 8). A dry period centred at around $1500 \mathrm{cal}$ а вP is recorded from Lake Mirabad in western Iran (Stevens et al., 2006). A synchronous dry period has been proposed in studies from neighbouring regions. Studying sediments from the Aegean Sea, Ehrmann et al., (2007) inferred a dry period lasting from 1700 to $1000 \mathrm{cal}$ a BP for the north and south catchments of the sea. Also, palaeoclimate reconstruction studies in Anatolian lakes suggest centennial-scale dry climatic conditions for the period between 1800 and 1300 cal yr вP (see Ocakoğlu et al., 2016).

Towards the last few centuries, the Neor Lake pollen diagram shows the expansion of steppe and/or anthropogenic-type vegetation in the studied area, as one

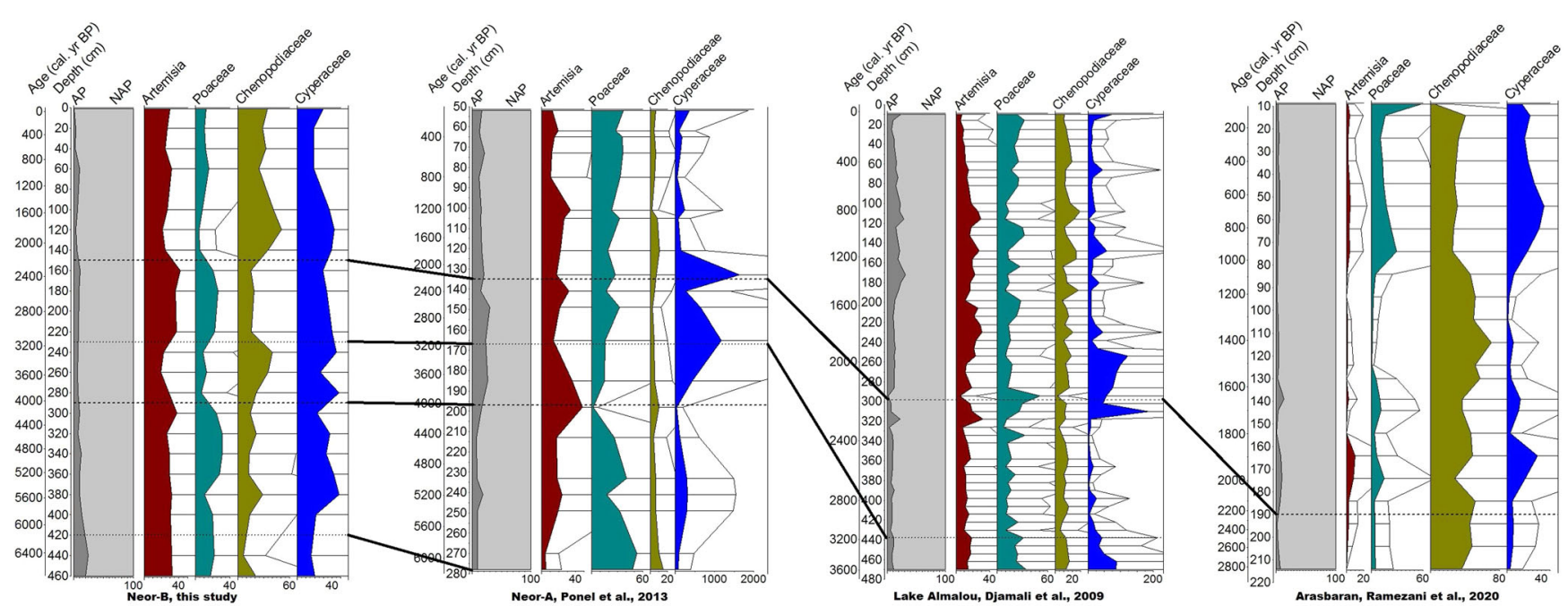

Figure 8. Tentative correlation between palynological spectra in Neor-B core (this study) and other pollen records from northwestern Iran. [Color figure can be viewed at wileyonlinelibrary.com]. 
might have expected. This can be inferred from the relative increase of such pollen types as Ephedra distachya, Centaurea solstitialis and Plantago lanceolata (see Fig. 4). To reiterate, the second axis of the PCA is mostly represented by a number of disturbance pollen taxa such as Centaurea solstitialis type, Plantago lanceolata type, Euphorbia, Solanum nigrum, Cirsium and Carpesium, which could be attributed to azonal anthropogenic landscapes (see e.g. Zohary 1973) rather than specific climatic conditions. Djamali et al., (2009) postulate that Centaurea solstitialis-type pollen might indicate cereal cultivation and pollen of Plantago lanceolata-type can be considered as an indicator for grazing expansion in the highlands of northwestern Iran. Today, the vegetation around Lake Neor is under strong grazing activity as evidenced by the presence of many ruderal plants including different Rumex and Plantago species (Ghahremaninejad et al., 2012; Alinezhad et al., 2017).

Today, the nomado-pastoral seasonal settlers spend their summer in the lake region and their activities have a large impact on the naturally growing vegetation. Similar nomadopastoral activities may have been practised for more than a millennium (Ponel et al., 2013), and were intensified after the arrival of Turkish nomadic people during the Middle Ages and contributed to the maintenance of an overgrazed open steppe landscape. Similarly, intensified human activities as the major driver of the establishment and maintenance of modern vegetation and land use changes has also been proposed for the Lake Urmia and Lake Almalou regions (Djamali et al., 2009; Mokarizadeh et al., 2016; Talebi et al., 2016).

\section{Conclusion}

Palynological and geochemical data obtained from a peripheral peatland south of Lake Neor enabled reconstruction of local and regional vegetation history of this part of northwestern Iran under the influence of climate change and human activities over the past 7000 years. The Neor pollen record is overwhelmingly composed of pollen types attributable to Artemisia spp., Chenopodiaceae and Poaceae, a typical feature of Irano-Turanian montane steppes. Frequent rather wet (6710-6200 cal а вP; 5400-4600 cal a вP; 3200-2200 cal а вP) and dry (5800-5400 cal a BP; $4030-3200 \mathrm{cal}$ a BP; $2200 \mathrm{cal} \mathrm{a} \mathrm{BP}$ to present) cycles were recorded over the past seven millennia. However, long-term human activity in the area can be deduced from the occurrence of anthropogenic pollen indicators such as Centaurea solstitialis-type and Plantago lanceolata-type and the Late Holocene prominent peaks of charcoals.

On the basis of the PCA analysis, climate change (from wet to dry conditions) seemed to be the main environmental gradient affecting vegetation composition in the area. However, the second important gradient as characterised by disturbance pollen types, was probably driven by climateindependent factors such as grazing, mowing and other types of land use. Overall, our pollen record indicates that over the past seven thousand years, despite a few wet periods, dry climatic conditions and Irano-Turanian steppe vegetation prevailed in the highlands of northwestern Iran. We find that the multiproxy approach we employed in this study, albeit not free from age-model caveats, provided a more comprehensive image of how plants responded to abrupt climate change. However, the role of anthropogenic influence on plant diversity in the Lake Neor basin area over the last two millennia remains far from being fully explored. The different nature of the proxies (biological versus physico-chemical) suggests that an accurate interpretation of these datasets together must take into account their multiscale responses to environmental changes both spatially and temporally.

\section{Supporting information}

Additional supporting information can be found in the online version of this article.

Acknowledgements. This study was partly funded by the French project ANR PALEO-PERSEPOLIS (ANR-14-CE35-0026-01). We wish to thank the Management of the Iranian National Institute for Oceanography and Atmospheric Sciences (INIOAS) and particularly Drs Hamid Alizadeh Lahijani and Abdolmajid Naderi-Beni for their support during the fieldwork. We are grateful to Dr Hadi Beygi (Urmia University), Dr Mateusz Płóciennik (Unversity of Lodz, Poland) and Taravat Talebi (University of Groningen) for contributing in the preparation of Figs. 1 and 8. Drs Philippe Ponel, Majid ShahHosseini and Mr Assadollah Taheri are acknowledged for their assistance during the fieldwork. Dr Mahmoud Bidarlord (Watershed Management and Forests and Rangelands Research Department, AREEO, Rasht, Iran) is thanked for helpful discussions on the main vegetation communities of the study area and for useful comments on Fig. 1. The manuscript was greatly improved by comments from two anonymous reviewers, for which we are very grateful.

Author contributions-Khadijeh Alinezhad: Fieldwork; pollen analysis; writing preliminary draft. Elias Ramezani: Research design; fieldwork; pollen analysis and interpretation; writing, review and editing (lead). Morteza Djamali: Research design; fieldwork; interpretation of pollen data; review and editing. Arash Sharifi: Geochemical analysis; writing, review and editing. Alireza Naqinezhad: Fieldwork; ordination analysis; writing, review and editing. Cyril Aubert: Age-depth model; review. Emmanuel Gandouin: Interpretation of ordination; review. Ali Pourmand: Geochemical analysis; review and editing.

\section{Data availability statement}

All pollen data will be made available in European pollen database.

\section{References}

Algeo Th, Maynard B. 2004. Trace-element behavior and redox facies in core shales of Upper Pennsylvanian Kansas-type cyclothems. Chemical Geology 206: 289-318.

Alinezhad Kh, Ramezani E, Naqinezhad AR et al. 2017. A preliminary floristic study of Neor high altitude wetland, Ardebil province, NW Iran. Journal of Forest Research and Development 3: 221-235 (in Persian with English abstract).

Assadi M. 1998. Noteworthy plant records for the flora of Iran. Iranian Journal of Botany 7(2): 217-220.

Aubert C, Brisset E, Djamali M et al. 2017. Late glacial and early Holocene hydroclimate variability in northwest Iran (Talesh Mountains) inferred from chironomid and pollen analysis. Paleolimnology 17(2): 151-167.

Barber KE. 1981. Peat Stratigraphy and Climatic Change: A Palaeoecological Test of the Theory of Cyclic Peat Bog Regeneration. Balkema: Rotterdam; 219.

Bar-Matthews M, Ayalon A. 2011. Mid-Holocene climate variations revealed by high-resolution speleothem records from Soreq Cave. Israel and their correlation with cultural changes. The Holocene 21: 163-171.

Bar-Matthews, M, Ayalon A, Gilmour M et al. 2003. Sea-land oxygen isotopic relationships from planktonic foraminifera and speleothems in the Eastern Mediterranean region and their implication for paleorainfall during interglacial intervals. Geochimica et Cosmochimica Acta 67: 3181-3199.

Beug HJ. 2004. Leitfaden der Pollen bestimmung fur Mitteleuropa und Angrenzende Gebiete. Verlag Dr. Friedrich Pfeil Publications: Germany. 
Birks HJB. 2012. Ecological palaeoecology and conservation biology: controversies, challenges, and compromises. Biodiversity Science. Ecosystem Services \& Management 8: 292-304.

Blaauw M. 2010. Methods and code for 'classical' age-modelling of radiocarbon sequences. Quaternary Geochronology 5: 512-518.

Bottema S. 1986. A late Quaternary pollen diagram from Lake Urmia (northwestern Iran). Review of Palaeobotany and Palynology 47: 241-261.

Brisset E, Djamali M, Bard E et al. 2018. Late Holocene hydrology of Lake Maharlou, southwest Iran. inferred from high-resolution sedimentological and geochemical analyses. Paleolimnology 48: 151-167.

Calvert SE, Pedersen TF. 1993. Geochemistry of Recent Oxic and Anoxic Marine Sediments Implications for the Geological Record. Marine Geology 113: 67-88.

Calvert SE, Pedersen TF. 2007. Elemental proxies for palaeoclimatic and palaeoceanographic variability in marine sediments: interpretation and application. In Proxies in Late Cenozoic Paleoceanography, Hillaire-Marcel C, Vernal AD (eds). Elsevier: Amsterdam; 567-644.

Chase MW, Christenhusz MJM, Fay MF et al. 2016. An update of the Angiosperm Phylogeny Group classification for the orders and families of flowering plants: APG IV. Botanical Journal of the Linnean Society 181(1): 1-20.

Connor SE, Sagona A. 2007. Environment and society in the late prehistory of Southern Georgia, Caucasus. In Les cultures du Caucase (Vle- Ille millénaires avant notre ère) e Leurs relations avec le Proche-Orient, Lyonnet B (ed). Editions Recherche sur les Civilisations. CNRS Editions: Paris; 21-36.

Cullen HM, de Menocal PB, Hemming S et al. 2000. Climate change and the collapse of the Akkadian empire: evidence from the deep sea. Geology 28: 379-382.

Dearing JA. 2006. Climate-human-environment interactions: resolving our past. Climate of the Past 2: 187-203.

Dehghani M, Djamali M, Gandouin E et al. 2017. A pollen rainvegetation study along a $3600 \mathrm{~m}$ mountain-desert transect in the Irano-Turanian region; implications for the reliability of some pollen ratios as moisture indicators. Review of Palaeobotany and Palynology 247: 133-148.

Djamali M, de Beaulieu JL, Shah-Hosseini M et al. 2008. A late Pleistocene long pollen record from Lake Urmia, NW Iran. Quaternary Research 69: 413-420.

Djamali M, de Beaulieu JL, Andrieu-Ponel V et al. 2009. A Late Holocen pollen record from Lake Almalou in NW Iran: evidence for changing land-use in relation to some historical events during the late 3700 years. Journal of Archaeological Science 367: 1346-1375.

Djamali M, Akhani H, Andrieu-Ponel V et al. 2010. Indian Summer Monsoon variations could have affected the early-Holocene woodland expansion in the Near East. The Holocene 20: 813-820.

Djamali M, Akhani H, Khoshravesh R et al. 2011. Application of the Global Bioclimatic Classification to Iran: implications for understanding the modern vegetation and biogeography. Mediterranean Ecology 37: 91-114.

Ehrmann W, Schmiedl G, Hamann Y et al. 2007. Clay minerals in late glacial and Holocene sediments of the northern and southern Aegean Sea. Palaeogeography Palaeoclimatology Palaeoecology 249(1): 36-57.

El-Moslimany AP. 1990. Ecological significance of common nonarboreal pollen: examples from drylands of the Middle East. Review of Palaeobotany and Palynology 64: 343-350.

Fægri K, Iversen J. 1989. Textbook of pollen analysis (revised by Fagri K, Kaland PE, Krzywinski K). John Wiley and Sons; 328.

Frey W, Kürschner H, Probst W. 1999. Flora and vegetation, including plant species and larger vegetation complexes in Persia. In Encyclopedia Iranica, Yarshater E (ed.) 10. Bibliotheca Persia Press: New York; 46-63.

Gámiz F, Martínez-Ruiz S, Rampen W et al. 2014. Sea surface temperature variations in the western Mediterranean Sea over the last 20 kyr: a dual-organic proxy (UK'37 and LDI) approach. Paleoceanography 29(2): 87-98.

Ghahremaninejad F, Bidarlord M, Attar F. 2012. Floristic study of steppe parts of Lissar protected area (N Iran). Rostaniha 13(2): $164-188$.
Grimm EC. 1987. CONISS: a FORTRAN 77 program for stratigraphically constrained cluster analysis by the method of incremental sum of squares. Computers \& Geosciences 13(1): 13-35.

Grimm EC. 2015. TILIA Software. Version 2.0.41. Illinois State Museum: Springfield.

Hedges J, Stern J. 1984. Carbon and nitrogen determinations of carbonate containing solids. Limnology and Oceanography 29: 657-663.

Janssen CR. 1973. Local and regional pollen deposition. In Quaternary plant ecology, Birks HJB, West RG. (eds). 14th Symposium of the British Ecological Society; 31-42.

Kaniewski D, Paulissen E, Van Campo E et al. 2008. Middle East coastal ecosystem response to middle-to-late Holocene abrupt climate changes. Proceedings of the National Academy of Sciences of the United States of America 105: 13941-13946.

Kazancı N, Gulbabazadeh T, Leroy S et al. 2016. Aeolian control on the deposition of high altitude lacustrine basins in the Middle East: The case of Lake Neor, NW Iran. Quaternary International 408: 65-77.

Klein JC, Lacoste A. 1995. Les pozzines àCarex orbicularis Boott subsp. kotschyana del'Alborz central (Iran): groupement à la charnière des regions euro-siberienne et iranotouranienne. Ecologia Mediterranea 12: 75-86.

Kuzucuoğlu C, Dorfler W, Kunesch S et al. 2011. Mid-to lateHolocene climate change in central Turkey: the Tecer Lake record. The Holocene 1: 173-188.

Madadi A, Moghaddam MHR, Rajaei AH. 2005. Study of the geomorphological evolution of the Neor Lake in Ardabil region, NW Iran. Geography Researches 618: 1-20 (in Persian with English abstract).

Martinez-Ruiz F, Kastner M, Gallego-Torres D et al. 2015. Paleoclimate and paleoceanography over the past $20,000 \mathrm{yr}$ in the Mediterranean Sea Basins as indicated by sediment elemental proxies. Quaternary Science Reviews 107: 25-46.

Martini IP, Cortizas MA, Chesworth W (eds). 2006. Peatlands: evolution and records of environmental and climate changes. Elsevier: Amsterdam; 587.

Migowski C, Stein M, Prasad S et al. 2006. Holocene climate variability and cultural evolution in the Near East from the Dead Sea sedimentary record. Quaternary Research 66: 421-431.

Mittermeier RA, Turner WR, Larsen FW et al. 2011. Global biodiversity conservation: the critical role of hotspots. In Biodiversity hotspots, Zachos FE, Habel JC (eds). Springer: Berlin, Heidelberg.

Messager E, Belmecheri S, Von Grafenstein U et al. 2013. Late Quaternary record of the vegetation and catchment-related changes from Lake Paravani (Javakheti, South Caucasus). Quaternary Science Reviews 77: 125-140.

Mokarizadeh A, Ramezani E, Naqinezhad A et al. 2016. Palynological reconstruction of 1700 years vegetation dynamics in suburban Urmia, northwestern Iran: the role of climate and humans. Physical Geography Research Quarterly 48: 385-395 (in Persian with English abstract).

Moore PD, Webb JA, Collinson ME. 1991. Pollen Analysis, Second Ed. Blackwell Science Publishers: Oxford; 216.

Muller J, Kylander M, Martinez-Cortizas A et al. 2008. The use of principle component analyses in characterising trace and major elemental distribution in a $55 \mathrm{kyr}$ peat deposit in tropical Australia: Implications to paleoclimate. Geochimica et Cosmochimica Acta 72: 449-463.

Naafs BDA, Inglis GN, Zheng $\mathrm{Y}$ et al. 2017. Introducing global peat-specific temperature and $\mathrm{pH}$ calibrations based on brGDGT bacterial lipids. Geochimica et Cosmochimica Acta 208: 285-301.

Nagashima K, Tada R, Tani A et al. 2011. Millennial-scale oscillations of the westerly jet path during the last glacial period. Asian Earth Science 40: 1214-1220.

Naqinezhad A, Nowak A, Świerszcz S et al. 2021. Syntaxonomy and biogeography of the Irano-Turanian mires and springs. Applied Vegetation Science. in press.

Ocakoğlu F, Oybak Dönmez E, Akbulut A et al. 2016. A 2800-year multi-proxy sedimentary record of climate change from Lake Çubuk (Göynük, Bolu, NW Anatolia). The Holocene 26(2): 205-221.

Ponel P, Andrieu-Ponel V, Djamali M et al. 2013. Fossil beetles as possible evidence for transhumance during the middle and late 
Holocene in the high mountains of Talysch (Talesh) in NW Iran. Journal of Environmental Archaeology 18: 201-210.

Prentice C, Guiot J, Huntley B et al. 1996. Reconstructing biomes from palaeoecological data: a general method and its application to European pollen data at 0 and 6 ka. Climate Dynamics 12: 185-194.

R Core Team. 2012. R: A language and environment for statistical computing. R Foundation for Statistical Computing: Vienna.

Ramezani E, Marvie Mohadjer MR, Knapp HD et al. 2013. Pollenvegetation relationships in the central Caspian (Hyrcanian) forests of northern Iran. Review of Palaeobotany and Palynology 189: 38-49.

Ramezani E, Talebi T, Alizadeh K et al. 2020. Long-term persistence of steppe vegetation in the highlands of Arasbaran protected area, northwestern Iran, as inferred from a pollen record. Palynology 45: 15-26.

Reimer PJ, Bard E, Bayliss A et al. 2013. IntCal13 and Marine13 Radiocarbon Age Calibration Curves 0-50,000 Years cal BP. Radiocarbon 55: 1869-1887.

Roberts N, Jones MD, Benkaddour A et al. 2008. Stable isotope records of Late Quaternary climate and hydrology from Mediterranean lakes: the ISOMED synthesis. Quaternary Science Reviews 27: 2426-2441.

Roberts N, Wright HE. 1993. Vegetational, lake-level, and climatic history of the Near East and Southwest Asia. In Global climates since the last glacial maximum, Wright HE Jr, Kutzbach JE, Webb T III et al. (eds). University of Minnesota Press: Minneapolis; 194-220.

Roberts N, Reed J, Leng MJ et al. 2001. The tempo of Holocene climatic change in the eastem Mediterranean region: new highresolution crater-lake sediment data from central Turkey. The Holocene 11: 721-736.

Robinson SA, Black S, Sellwood BW et al. 2006. A review of palaeoclimates and palaeoenvironments in the Levant and Eastern Mediterranean from 25,000 to 5000 years BP: setting the environmental background for the evolution of human civilisation. Quaternary Science Reviews 25: 1517-1541.

Rodrigo-Gámiz M, Martínez-Ruiz F, Rodríguez-Tovar FJ et al. 2014. Millennial- to centennial-scale climate periodicities and forcing mechanisms in the westernmost Mediterranean for the past 20,000 yr. Quaternary Research 81: 78-93.

Rossignol-Strick M. 1995. Sea-land correlation of pollen records in the Eastern Mediterranean for the glacial-interglacial transitions: Biostratigraphy versus radiometric time-scale. Quaternary Science Reviews 14: 893-915.

Rossignol-Strick M. 1999. The Holocene climatic optimum and pollen records of sapropel 1 in the eastern Mediterranean, 9000-6000 BP. Quaternary Science Reviews 18: 515-530.

Schiemann R, Lüthi D, Schär C. 2009. Seasonality and interannual variability of the westerly jet in the Tibetan Plateau region. Journal of Climate 22: 2940-2957.

Schilman B, Bar-Matthews M, Almogi-Labin A et al. 2001. Global climate instability reflected by Eastern Mediterranean marine records during the late Holocene. Palaeogeography, Palaeoclimatology, Palaeoecology 176: 157-176.

Sharifi A, Pourmand A, Canuel E et al. 2015. Abrupt climate variability since the last deglaciation based on a high-resolution, multiproxy peat record from NW Iran: The hand that rocked the Cradle of Civilization. Quaternary Science Reviews 123: 215-230.
Sharifi A, Murphy LN, Pourmand A et al. 2018. Early-Holocene greening of the Afro-Asian dust belt changed sources of mineral dust in West Asia. Earth and Planetary Science Letters 481: 30-40.

Shumilovskikh LS, Hopper K, Djamali M et al. 2016. Landscape evolution and agro-sylvo-pastoral activities on the Gorgan Plain (NE Iran) in the last 6000 years. The Holocene 26: 1676-1691.

Stevens LR, Ito E, Schwalb A et al. 2006. Timing of atmospheric precipitation in the Zagros Mountains inferred from a multi-proxy record from Lake Mirabad, Iran. Quaternary Research 66: 494-500.

Stockmarr J. 1971. Tablets with spores used in absolute pollen analysis. Pollen et Spores 13: 615-21.

Talebi T, Ramezani E, Djamali M et al. 2016. The Late-Holocene climate change, vegetation dynamics, lake level changes and anthropogenic impacts in Lake Urmia region, NW Iran. Quaternary International 408: 40-51.

ter Braak CJF. 1987. Ordination. In Data Analysis in Community and Landscape Ecology, Jongman RH, ter Braak CJF, van Tongeren OFR (eds). Pudoc: Wageningen.

van Geel B, Mauquoy M. 2010. Peatland archives of late-Holocene climate change in northern Europe. PAGES Newsletter 18(1): 4-6.

van Zeist W, Bottema S. 1977. Palynological investigations in Western Iran. Palaeohistoria 19: 19-85.

Walker M, Head MJ, Berkelhammer M et al. 2018. Formal ratification of the subdivision of the Holocene Series/Epoch (Quaternary System/Period): two new Global Boundary Stratotype Sections and Points (GSSPs) and three new stage/subseries. Episodes 41: 213-223.

Walker M, Gibbard P, Head MJ et al. 2019. Formal subdivision of the Holocene series/epoch: a summary. Journal of the Geological Society of India 93: 135-141.

Weiss H. 2016. Global megadrought, societal collapse and resilience at 4.2-3.9 ka BP across the Mediterranean and west Asia. PAGES Magazine 24: 62-63.

Wick L, Lemcke G, Sturm M. 2003. Evidence of Lateglacial and Holocene climatic change and human impact in eastern Anatolia: high-resolution pollen, charcoal, isotopic and geochemical records from the laminated sediments of Lake Van, Turkey. The Holocene 13: 665-675.

Woodbridge J, Roberts N. 2011. Late Holocene climate of the Eastern Mediterranean inferred from diatom analysis of annually-laminated lake sediments. Quaternary Science Reviews 30(23): 3381-3392.

Wright HE, Andrews JH, van Zeist W. 1967. Modern pollen rain in western Iran, and its relation to plant geography and Quaternary vegetational history. Ecology 441-443.

Zachary PT, Horn SP, Mora CL et al. 2010. A multi-proxy palaeoecological record of late-Holocene forest expansion in lowland Bolivia. Palaeogeography, Palaeoclimatology, Palaeoecology 293: 98-107.

Zavvar A, Ramezani E, Naqinezhad A et al. 2017. Palynological analysis of the Late-Holocene vegetation and climate of Ganli-Gol wetland near Urmia, northwestern Iran. Iranian Journal of Forest and Poplar Research 25: 82-94 (in Persian with English abstract).

Zhao Y, Liu H, Li F et al. 2012. Application and limitations of the Artemisia/Chenopodiaceae pollen ratio in arid and semi-arid China. The Holocene 22: 1385-1392.

Zohary M. 1973. Geobotanical foundations of the Middle East. Stutgart: Gustav Fischer Verlag: Stuttgart; 739. 